\title{
Stock Theft: Rural Livestock Farmers' Entrepreneurial Perspectives
}

\author{
Mkateko Vivian Mabunda ${ }^{1}$, Witness Maluleke ${ }^{2, *}$, Jaco Barkhuizen $^{3}$ and \\ Willie Johannes Clack $^{4}$
}

\begin{abstract}
${ }^{1}$ Department of Public Management, Tshwane University of Technology / Human Resource Officer, Department of International Relations and Cooperation (DIRCO), South Africa

${ }^{2}$ Department of Criminology and Criminal Justice, School of Social Sciences, Faculty of Humanities, University of Limpopo (UL) - University of South Africa (UNISA), Department of Police Practice, College of Law, South Africa

${ }^{3}$ Department of Criminology and Criminal Justice, School of Social Sciences, Faculty of Humanities, UL, South Africa

${ }^{4}$ Department of Corrections Management [Penology], School of Criminal Justice, College of Law, University of South Africa, South Africa
\end{abstract}

\begin{abstract}
The collation between stock theft and rural livestock farmers' entrepreneurial perspectives receive limited attention in the field of Criminology and Criminal Justice, as well as 'Business Administration' nor entrepreneurial dominance industry. Conventionally, stock theft is nothing new in South Africa, traditional interpretations and recorded cases can be reportedly traced back to 1806 . This study reflects the duality of stock theft, offering criminological [Theoretical] explanations and glimpses of attractive business enterprises by adopting the three elements of 'Timmons Model of Entrepreneurial Process' through the use of non-empirical research design: Systematic review, while featuring the most affected areas by stock theft in the Eastern Cape (EC), KwaZulu-Natal (KZN) and Mpumalanga (MP) Provinces respectively, while focusing on 2014-2020 financial years. This study establishes provides that this crime, instead of making more business avenues for rural livestock farmers, will continue to decrease the number of job opportunities. It is recommended that the South African government (I.e. national, provincial and local levels), agricultural industries, and the local South African Police Service Stock Theft Units (SAPS STUs) as a collective and commodity organisations will have to gravely consider offering adequate services required to bring workable solutions for initiation of entrepreneurial activities in the selected provinces.
\end{abstract}

Keywords: Eastern Cape, Entrepreneur, Rural livestock farming practices, Kwa-Zulu Natal, Mpumalanga, Rural farmers, South Africa, Stock theft.

\section{INTRODUCTION AND PROBLEM FORMULATION}

Stock theft results in traumatic stress and threats to the economic lifeline of various rural farmers when their livestock gets stolen. Therefore, the associated effects become more severe to small-scale farmers, compared to the large scale who may have monetary resources for a speedy recovery. Importantly; livestock farming tends to be a greater source of income. Negatively; this sector currently gained criminal enterprises, becoming synonymous with criminality across the rural areas of Africa for criminals who want to pursue their selfish financial gains (Bunei, 2017). Historically, though regarded as a societal thorn issue; stock theft is not a novel phenomenon, it is probably touted to be old as agriculture itself, however, it has now taken a new nature; where it is committed by structured and well-

*Address correspondence to this author at the Department of Criminology and Criminal Justice, School of Social Sciences, Faculty of Humanities, University of Limpopo (UL) - University of South Africa (UNISA), Department of Police Practice, College of Law, South Africa; Tel: 012268 4881;

E-mail: witness.maluleke@ul.ac.za planned collectives of criminals, as opposed to the usually expected crime perpetrators or petty thieves.

It is reported that approximately $87 \%$ of stock theft features some form of organised crime, while $13 \%$ is for survival (Chelin, 2019). The preliminary planning of this crime takes sophisticated, organised, and resource-based, aided with greediness (Geldenhuys, 2020). The livestock farming practices [Rural business enterprises included] enhance the livelihood of persons residing in rural settings of third world nations, such as South Africa. The majority of these individuals are cited to be poor, earning their respective incomes from livestock farming practices, either in a direct or indirect manner. It should be noted that approximately $70 \%$ of people found in the Southern African Development Community (SADC) depend on "agriculture for food, income, and employment." This sub-sector [Livestock] contributes 30 to $80 \%$ of the agricultural Gross Domestic Product (GDP) in Africa, this conforms to the delivery of agricultural led growth and socio-economic transformations as envisioned in the 'Malabo 
Declaration on Accelerated Africa Agriculture Growth and Transformation' emphasising shared prosperity and improved livelihoods (Ben, Moreki, Wame, Kebadire \& Lesaba, 2018; and Mahlobo, 2016).

The ownership of livestock for many South African rural residents' areas are referred to as sources of stability, social and political influences. They are branded as valuable assets, providing "wealth, food, income, social identity, recognition, pride and status" and also act as a "symbol of prosperity and prestige." Livestock is also considered to be one of the major sources for money used by organised criminal networks to pursue their selfish financial gains." To this end; cattle for many native residents of South African rural communities, are not simply regarded as a source of food, they are also seen as an essential commodity used for negotiations and social investments. In general, the majority of South African rural communities see livestock as 'living wealth,' their only source of income and sustainability. Therefore, when stock theft occurs, it can be a traumatic experience, prompt to threaten economic lifeline and business enterprises attempted by rural livestock farmers. To this course; stock theft severely hits emerging subsistence/small-scale livestock farmers in the rural setting, with the commercial farmers and 'Red Meat Industry' feeling this unbearable pain (Geldenhuys, 2020).

While acknowledging the highlighted notions Supra, stock theft must be escalated and treated as a serious economic crime, it should be viewed in a very serious light. (Eye Witness News, 2020) and Pijoos (2020) collaborated that Minister of the Police Bhekokwakhe 'Bheki' Hamilton Cele wants better auditing of livestock and has vowed to crack the whip on crooked local SAPS members during a crime Imbizo [l.e. Gathering, usually called by a traditional leader, public sector officials nor communal leaders] with farmers in the Free State $(F S)$. He shared the following in disappointment: "I have seen the stock theft figures, it is hell. I do not know what sheep have done because they are stealing sheep. To me, this is economic sabotage and it is not an ordinary crime."

Nicolson and Simelane (2020) highlight that the South African police officials (Under SAPS STUs) tasked to police stock theft are allegedly reported to be corrupt, it was established that the local livestock farmers on the receiving end of crime, which they insist is not race-driven. However, for the many unemployed and desperate, theft of livestock is a way to survive.
[Livestock] farmers believed that culminations of factors relating to the policing of this crime and the inadequate justice system's to positively act on stock theft, coupled with high levels of unemployment, where stock theft is becoming a career for some individuals, one with apparently few consequences. Consequently; both Black and White farmers in the area dismissed race as an issue when it came to crime on the farms. They said [Stock] theft was common and criminals often intimidated and sometimes assaulted farmers and farmworkers, Nicolson and Simelane (2020).

It should also be understood that the rural livestock farmers consist of a more conservative segment of the population, referred to as a vulnerable part of society [l.e. often the poorest part of a country - especially rural smallholders] are predominantly impacted by stock theft. South Africa's agricultural sector expects the wider economic impact of stock theft to rise by R200 million this year, up to an estimated R1.3 billion from R1.1 billion recorded during the 2018 financial year, FTW Online (2019). Complementary to this, the Victims of Crime Survey [VOCS] (2017/2018) report provides that $0,05 \%$ and $0,77 \%$ of South African families experience great losses due to stock theft and grain theft. 'Goats,' were the most common livestock stolen, with the reported $30,6 \%$ of households affected, estimated to be over 170000 . In contrast, almost 270 000 sheep were stolen with roughly $19 \%$ of households affected. Also, 177000 head of cattle were stolen from $23,8 \%$ of the households. With $29 \%$ indicating households from which livestock was stolen more than once. Astounding $71 \%$ of all cases did not make it to the local SAPS nor courts. However, the rate of reporting improved slightly compared to 2016/2017, where only $26 \%$ of cases were reported. In contrast to this, the rate of stock theft reporting is not mentioned in the 2018/19 VOCS report (Lombard, 2020).

Equally important, Dean (2020) highlights that cattle, sheep, and goats worth more than R1,2 billion were stolen in South Africa during the 2018/2019 financial year, as provided according to statistics by the National Stock Theft Prevention Forum [NSTPF] (2019), this figure only applied to the value of animals stolen, causing greater concerns in the industry and did not account for additional costs, such as the "judicial process, farmer costs, recovery costs, and policing, among others." Moreover, approximately 30000 livestock heads were reported stolen for this period, the value of stolen cattle was about R900 million, with about R200 million worth of sheep stolen, and about R100 million of goats. Furthermore, the biggest losses 
were recorded in KZN Province, where the most cattle were stolen, followed by the EC, where the target was mostly sheep, and thereafter the FS, where thieves targeted both cattle and sheep. The biggest problem remains that. only about $20 \%$ of stock theft cases are reported, meaning that it is not known what the real figure is. This crime is often not reported owing to deficient trust in the local SAPS. Thus, the nonreporting of stock theft is at about $80 \%$ in South Africa. All indications concerning this crime point to a growing and worrying transnational organised crime element.

Notwithstanding, stock theft was on the rise in South Africa. The latest crime statistics of the SAPS confirmed this as it is reported that for the $2018 / 2019$ financial year, as released in September 2019 revealing a $2.9 \%$ climb from 2017/2018. With 29 672 recorded cases, stock theft costs the country billions of rand yearly, this damages the local agricultural economy and negatively impacts food security. The NSTPF, livestock to the value of R1.24 billion have been stolen in South Africa during 2018/2019. This can push a farm into ruin, revealing instances where livestock farmers are forced out of their business enterprises as a result of the experienced losses (Geldenhuys, 2020). Rarely, property-related crime, referring to theft occurring where an owner is not present, like stock theft continued the slow down a bit, with a steady decline of $4.2 \%$ recorded since 2013/14for the 2019/2020 financial year (Nicolson, 2020).

Grobler (2019) states that a serious financial loss experienced by the members of the South African 'Farmer Associations' is caused by stock theft as one of the property-related crimes. However, the farming community also experiences trauma instigated by home burglaries. This community is progressively exposed to crime such as theft, smuggling, and devastation of farm infrastructure. Consequently, the livestock sector conundrum towards 2050. Corrigan (2019) shares that a severe threat to the farming economy is stock theft, whereas those who do not experience this crime [Stock theft] poorly understand its realities. It may be alluring to reason stock theft as an outlying action, it is extremely annoying than a threat. In essence, the threat that stock theft instigates to farmers in South Africa should not be underrated nor the impairment inflicted both to the local and national economy. This, however, is likely to progress until it receives far greater attention from society and priority from the government.
Additionally, Dr. Jane Buys [I.e. A Security Risk Analyst at FS Agriculture] divulges that from her experience in this province, stock theft is not limited to the established commercial farmers, but is a focal concern for smaller-scale evolving and subsistence farmers, as well as, contribution by substantial underreporting of the crime and it is also thought that the extent of stock theft is probably far greater than the official figures indicated. The second facet of stock theft is that the greater amounts of livestock that get stolen undeniably depict that the commission of these offences involves organised groups or syndicates, further validating claims by Clack (2019). Therefore, the Modus Operandi (MO) of stock theft operations. On the minimal-scale 'subsistence' side, minimal animals might be driven off, or annihilated and butchered for meat purposes by the thieves taking off with whatever they can carry. Enormously, more erudite syndicates will engage in what is fundamentally a planned incursion. A group of people will break onto the property, with an intent to drive off tons of animals. This might be done on foot, initially at least, but they will at some point commonly be loaded onto trucks and hastily be transported away from the crime scene. Thus, poaching and stock theft in South Africa is the focal concern to game production and livestock. This eventually impacts the country's economy, affecting every farming sector within the community, ranging from the great commercial organisations to the stud breeders and circulating to the rural farmers who may own just one or two animals. Consequently, stock theft has broader implications than the loss of animals; food security is also affected by this issue, Animal Research Council [ARC] (2014).

However, net benefits such as food production (I.e. Milk and meat), raw materials (Wool) are provided by livestock. Thus, livestock provides a net benefit such as food production (Milk and meat), raw materials (Wool), draught, manure, cultural practices, revenue, and investment can improve the resilience of smallholder mixed crop-livestock farmers in developing countries, against the external susceptibilities such as scarcity of water and climate change (Dedekind, 2016). Lombard (2015) opines that stock theft is not anew established crime that every individual is concern about in Africa, it is as nonmodern as farming itself. Recorded cases on stock theft in the Amersfoort region of MP and South Africa as a whole can be traced back to 1806. In these memory days, thieves ravaging the rural regions of Africa to take advantage of rich pickings, a discrete environment, and relatively minimal risk, and rural 'hot products.'Across Africa in general and South Africa 
specifically, stock theft is obstinate, posing a serious threat to food security and livelihood development (Bunei, 2017).

The Agriculture South Africa [Agri SA] (2018) declares that almost seven out of ten South African commercial farmers partook in the recent study by the Agri SA experienced one or other form of crimes during the year 2017, this is one of the numerous staggering facts regarding the nature of the crime that South African farmers experience daily.

Lombard (2017) shares that determining the value of stolen animals remains a serious challenge for farmers. When determining the minimum and maximum replacement values, the study beneath can serve as a handy guide to calculate a fair replacement price (Macaskill, 2018). The total value of agriculture by the livestock sector accounts for more than $40 \%$.

Putting aside the obvious economic impact, this crime renders an unsettling psychological impact on livestock farmers. The owners of livestock can be gravely emotive about the loss of their animals, they regard them as living beings, not mere objects (Corrigan, 2019). Looking at the pictures depicting how these livestock gets injured and mutilated by criminals, the difficulties experienced by the livestock farmers can be understandable, they often encounter mass slaughtering and maimed livestock. Contrary to financial losses; these livestock farmers feel helpless and furious against those who commit this crime. The biggest concerns are associated with livestock sufferings (Geldenhuys, 2020). Comparatively, good livestock market prices, favourable seasonal conditions, and increased feed are contributing factors to stock theft in Australia. It is shared that "criminals often work on a risk versus reward mentality ... Currently, the reward, or price of the commodity, is at record high levels ... The risk can be seen as lower due to the seasonal conditions encouraging the offenders to believe they may not need to sell the stolen livestock shortly to achieve the reward. They can use them to grow wool, breed the stock, among others and take advantage of the seasonal conditions ... In the past five years, from 2015 to 2019, an estimated $\$ 18$ million - R302 978700,00 , by the time of conducting this study, the worth of cattle and sheep have been reported stolen in New South Wales (NSW) ... This is a conservative estimate of the financial loss to primary producers within NSW. This value does not include the stud stock, loss of breeding potential, and animal bi-product," Morton (2020).
This study provides that the African cultures cattle prowling [Stock theft] created the utmost part of warfare. Equally, the South African Society for Animal Science reports that stock theft is one of South Africa's most persistent crimes with about 400000 domestic animals, valued at more than R1 billion reported stolen between 2006 and 2010, with 2018 still showing an estimation of R1 billion losses suffered in this sector and 2019 showing an increase of $2.9 \%$, the number of stolen livestock increased by $9.2 \%$ on average and this number is expected to further escalate in 2020, subsequently, Northern and Western parts of KZN, Northern-Eastern FS, and MP are perceived as the most affected regions. African countries, such as; Lesotho, Kenya, Eritrea, Nigeria, Argentina, Australia, Brazil, California, Chile, New Zealand, Paraguay, Texas and Oklahoma, United States, and Uruguay are not immune to this crime. Although limited research on this topic is available, none are truly applicable to South African contexts. None of the available studies explore stock theft as a hindrance to the envisaged rural livestock farming practices as a form of entrepreneurship. The rural livestock farmers' characteristics in terms of coping with this crime across the world suggest that this sector consists of a more conservative segment of the population often regarded as anchors of economic activities in their respective areas; they are [More] vulnerable part of society [Often the poorest part of a country - especially rural smallholders], which normally further away from services of the local SAPS and more involved with community surroundings and community life; from the commercial side, they are job creators, often the closest source of food and crime [Stock theft] targets.

Understanding the application of the 'Entrepreneurial Process Model'developed by Jeff Timmons (Dr. Timmol) on stock theft as depicted in Figure 1 of this study. According to Timmons (1999), the Entrepreneurial Process Model encompasses three foremost entrepreneurial components: Opportunity, resources, and team. These three aspects are the main of any entrepreneurial venture. If one of the components is omitted or is inadequate, the success of the new venture is highly unlikely, Stanford University's Entrepreneurship (Corner, 2006). This model grants that successful entrepreneurship is a challenge in itself including livestock farmers. It is stated that when external forces out of the entrepreneur's control are negative, the usual entrepreneurial challenges are compounded, stock theft can be a difficult aspect in this regard. The entrepreneurs are pivotal to the economy 


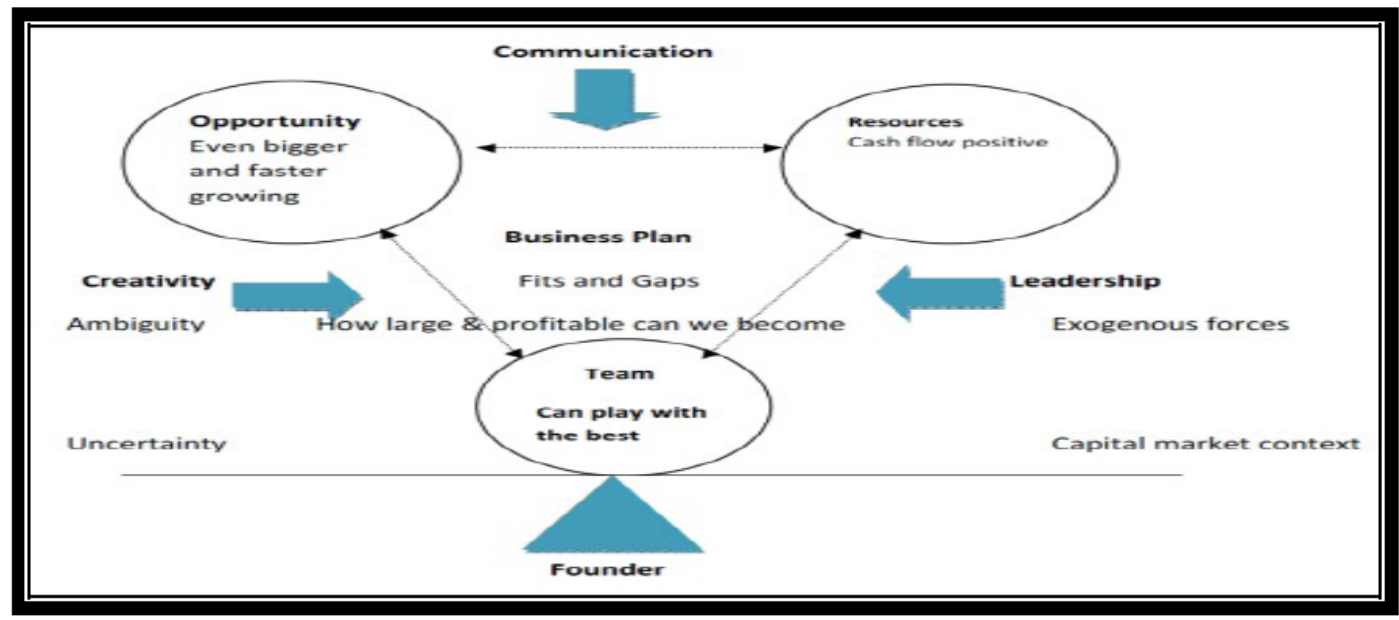

Figure 1: Critical factors for Timmons Model of the Entrepreneurial Process Model.

Source: Timmons (1999), Zeng, Bu and Su (2011) and Kaulitz (2012).

of South Africa as they bring investments into the county that in turn generates employment opportunities for others.

\section{MATERIALS AND METHODS}

This article followed a Non-empirical research design: Systematic Review. This study design refers to a research form that identifies, describes, appraises, and synthesises available research literature 'using systematic and explicit accountable methods (Gough, Oliver \& Thomas, 2012). In this case, the predetermined steps of this research design were followed to allow the researchers to enhance their understanding of this subject. Documents [I.e. Data solicited from electronic academic database, books, journals, and internet sources] (I.e. "... documents are something more than just a source of data since it is possible to research documents in their own right as a 'field' of research," Matthews and Ross (2010). Data was collected qualitatively using non-probability: Purposive sampling, aided by researchers' personal experiences, restricted from the financial year 1984 to 2019 (i.e. not in sequence), inclusion/exclusion criteria were applied during this process and the keywords/phrases were used to filter info relevant information on this subject based on the research problem. The Qualitative Content Analysis (QCA) referring to the data collection method or 'mixture of "analytic techniques" and procedure' (Flick, 2015). Thematic Analysis (TA) was used to analyse the collected data, Matthews and Ross (2010) state that "one can ask questions of documents in the same ways as with research respondents. For this article, the collected data was qualitative, expressing the ideas contained in the document in line with the underlying approach of the reviewed documents.

\section{PRELIMINARY LITERATURE REVIEW AND STUDY FINDINGS DISCUSSIONS}

First and most importantly; very little research exists that focuses solely on the combination between stock theft prevalence and preventions, as well as the rural livestock farming practices' entrepreneurial value. The ineffective implementation of business entrepreneurial activities in the rural setting becomes invaluable despite the notion that this crime poses greater challenges to the agricultural sector based on the premise that some of the related crimes are committed on farms or the farming sector, further affecting business operations. This is supported by Clack (2013) by stating that farming is one of the crucial bases of economic aptitude in any country. In light of this, the miscellaneous crimes committed in the rural agricultural areas call for research as they have a significant impact on the economy and food security if the nation cannot be underestimated. In essence; the significance of criminalities committed in the rural communities of the Republic of South Africa is somewhat overlooked by researchers in the field of humanities and related research areas. Clack (2019) also affirms that the 'Rural criminology' as a new topic of scholarly study neglected over the past two-to-three decades, has bounced into the spotlight, with claims being currently made that this study field is receiving justified attention among the academic fraternity. Internationally, the neglect of the rural areas is emphasised within the fairly this new study field, which is the scholarly study of crime in rural localities among 
the rural people around the world (Donnermeyer, 2016) (In Clack, 2018). According to (Maluleke, Mokwena, \& Motsepa, 2016), rural livestock farmers are not only facing challenges of severe drought blamed on the EI Nino weather pattern but the stock theft and lack of business enterprises as well. The local SAPS' Annual Crime Statistics Reports and Surveys respectively reveal that farmers of livestock in the rural communities are largely impacted by stock theft in South Africa. The amount of money paid for security services in their vicinities by the rural livestock farmers unevenly goes beyond the financial arrangement dedicated to production and business concepts. Considerably, the research on the extent, economic effects/impact, dark figures, and problem areas of stock theft in South African rural areas remain limited.

The sections covered in the paragraphs to follow look at the economic impacts of stock theft and the estimated value of livestock stolen and recovered, as well as the economic impacts of stock theft and depictions of the number of species stolen per year, as illustrated in Tables 1-3 and initially depicted Figure 1 respectively, further calling for criminological responses as well as anticipated financial losses. This was discussed in line with the Three (03) elements of Timmons' Model of the Entrepreneurial Process to gather rural livestock farmers' entrepreneurial perspectives on existing possibilities.

\section{THE ECONOMIC IMPACTS OF STOCK THEFT: A NEED FOR CRIMINOLOGICAL RESPONSES}

The Economist (2020) shares that "stock theft has been around since the Biblical times. However, in recent years it has reached ungodly proportions, many livestock is targeted to be stolen. In some places, it looks as if the farms are covered in poppy fields. In South Africa, 218,000 farm animals - Cows [Cattle], Sheep, or Goats were taken in the 12 months to March 2020 , up from 180,000 five years earlier. The total loss was worth about ( $\$ 60$ million) [900 million rands]. Livestock losses will probably be even higher, as the economic effects of the pandemic make it harder to earn a lawful living. A few decades ago pilferage was 'for the pot.' Today $87 \%$ of cases involve criminal syndicates, as initially indicated reveals Mr. Willie Clack of the University of South Africa (UNISA). Gangs act differently in different places. In parts of the FS and neighboring KZN thieves often load cows [Cattles] onto lorries, then cross into Lesotho. Inside the mountain kingdom, which is encircled by South Africa, syndicates rebrand Cattle before taking them back across the border, for sale at auction or to abattoirs. It is like

Table 1: Value of all Livestock Stolen and Recovered and the Resulting Financial Loss

\begin{tabular}{|c|c|c|c|c|c|c|}
\hline & $2013 / 2014$ & $2014 / 2015$ & $2015 / 2016$ & $2016 / 2017$ & $2017 / 2018$ & $2018 / 2019$ \\
\hline Stolen & R 788536200 & R 819045200 & R 877381700 & R 1058806200 & R 1222352592 & R 1243349100 \\
\hline Recovered & R 277475800 & R 301452200 & R 309211200 & R 324285400 & R 344104296 & R 314091600 \\
\hline Loss & R 511060400 & R 517593000 & R 568170500 & R 734520800 & R 878248296 & R 929257500 \\
\hline
\end{tabular}

Clack (2018) and NSTPF (2019).

Table 2: Value of Stolen Livestock and Recovered, and the Resulting Financial Loss Per Type of Animal

\begin{tabular}{|c|c|c|c|c|c|c|c|}
\hline & & $2013 / 2014$ & $2014 / 2015$ & $2015 / 2016$ & $2016 / 2017$ & $2017 / 2018$ & $2018 / 2019$ \\
\hline \multirow[t]{3}{*}{ Cattle } & Stolen & R 598017000 & R 610467000 & R 653148000 & R 796328000 & R 864812000 & R 918574800 \\
\hline & Recovered & R 231735000 & R 247632000 & R 251676000 & R 263965000 & R 266942000 & R 250153200 \\
\hline & Loss & R 366282000 & R 362835000 & R 401472000 & R 532363000 & R 597870000 & R 668421600 \\
\hline \multirow[t]{3}{*}{ Sheep } & Stolen & R 127540800 & R 143541200 & R 153183700 & R 180086000 & R 183286000 & R213 408300 \\
\hline & Recovered & R 26660800 & R 35523200 & R 38243200 & R 36006000 & R 34974000 & R 42231000 \\
\hline & Loss & R 100880000 & R 108018000 & R 114940500 & R 144080000 & R 148312000 & R 171177300 \\
\hline \multirow[t]{3}{*}{ Goats } & Stolen & R 62978400 & R 65037000 & R 71050000 & R 82392200 & R 94287600 & R 111366000 \\
\hline & Recovered & R 19080000 & R 18297000 & R 19292000 & R 24314400 & R 19676800 & R 21707400 \\
\hline & Loss & R 43898400 & R 46740000 & R 51758000 & R 58077800 & R 74610800 & R 89658600 \\
\hline
\end{tabular}

Clack (2018) and NSTPF (2019). 
Table 3: The Economic Impacts of Stock Theft

\begin{tabular}{|c|c|c|c|c|c|}
\hline & & $2016 / 2017$ & $2017 / 2018$ & $2018 / 2019$ & $2019 / 2020$ \\
\hline \multirow{3}{*}{$\begin{array}{l}\text { Overall } \\
\text { Statistics }\end{array}$} & Stolen & R 1058806200 & R 1142385600 & R 1214427000 & R 1179458600 \\
\hline & Recovered & R 324285400 & R 95718800 & R 307346600 & R 311642000 \\
\hline & Loss & R 734520800 & R 324100800 & R 907080400 & R 867816600 \\
\hline \multirow[t]{3}{*}{ Cattle } & Stolen & R 796328000 & R 864812000 & R 904657000 & R 862030000 \\
\hline & Recovered & R 263965000 & R 41068000 & R 246363000 & R 251160000 \\
\hline & Loss & R 532363000 & R 101178000 & R 658294000 & R 610870000 \\
\hline \multirow[t]{3}{*}{ Sheep } & Stolen & R 180086000 & R 183286000 & R 203246000 & R 206036000 \\
\hline & Recovered & R 36006000 & R 34974000 & R40 220000 & R 37470000 \\
\hline & Loss & R 144080000 & R148 312000 & R 163026000 & R168 566000 \\
\hline \multirow[t]{3}{*}{ Goats } & Stolen & R 82392200 & R 94287600 & R 106524000 & R111 392600 \\
\hline & Recovered & R 24314400 & R 19676800 & R 20763600 & R 23012000 \\
\hline & Loss & R58 077800 & R 74610800 & R 85760400 & R 88380600 \\
\hline
\end{tabular}

Source: Clack (2021).

laundering cars, but with Cows instead of Porsches. Stock theft can be seen through a racial lens. The victims of the largest heists in the FS are white Afrikaners who run big farms. Perhaps one-fifth of farm murders in the province allegedly including the highprofile killing of Brendin Horner, a 21-year-old farm manager, on October $1 \mathrm{st}$ is related to syndicates. Yet the victims in most cases of theft are black smallholders. As they own fewer animals, single incidents can ruin entire livelihoods, The Economist (2020).

Whites and blacks are both victims of a sclerotic Criminal Justice System (CJS). There are dedicated SAPS STUs within the police but they are siloed and poorly funded. A lack of arrests and prosecutions means there is 'no deterrence.' After the highlighted murder, it was then pledged that the responsible livestock syndicates are going to be investigated. Negatively; the livestock farmers in the FS were protecting themselves instead. On the contrary; those who can afford to find private solutions to stock theftrelated problems. Moreover, a 'Command Centre,' is also highly advised, as funded by 450 local farmers, using 65,000 Closed-Circuit Television (CCTV) cameras to look for livestock rustlers. Drones are also deployed, with Global Positioning System (GPS) tagging to find the purloined livestock, The Economist (2020).

Considerably; promoting agriculture is vital for addressing poverty issues, low employment rate, insufficient food and natural resources' sustainability in rural areas (Sehar, 2018). The animal product demand tends to increase with the growth of the population, particularly with the urbanisation that is rapidly growing (Sehar, 2018). The rise of demand for animal products in developing countries, linked with bigger public health awareness, which lays a foundation to promote marketing opportunities (Sehar, 2018). The production of livestock is a substantial agricultural enterprise in South Africa. For instance, almost eighty percent of South Africa's agricultural land is largely appropriated for farming extensively in livestock production; while other farming business equally combines livestock production. However, the livestock number varies per conditions of climate; leaving producers to concentrate mostly on breeds developed for adapting to different weathers and environments. It has been also noted that forty-nine percent (49\%) of agricultural outputs are contributed by this sector in South Africa. Up to eightyfive percent $(85 \%)$ of meat, requirements are usually produced in South Africa, while just fifteen percent $(15 \%)$ are imported from Europe and other countries such as Botswana, Namibia, Swaziland, New Zealand, and Australia, (Sehar, 2018). From the indications made in the introduction and problem formulation section, The Timmons' Model of the Entrepreneurial Process guided this study. The following components are discussed in line with the effects of stock theft on the South African livestock farmers and the envisaged business model.

Divergent from popular belief, stock theft is not exclusive to a specific continent, country, or region. This crime occurs globally and manifests on a variety of 
scales and degrees across countries, having been perpetuated from the period livestock herders, first tamed the aurochs in 7000 Before the Common Era (BCE), and being the first crime to attract a Restorative Justice (RJ) sentence mentioned in the Bible (Clack, 2018). Internationally, 'stock theft' is defined as 'a robbery involving the theft of livestock.' National statistics on crime refer to criminal offences as defined by each country's criminal law system (Anon, 2015). Different terms are employed in different areas of the world when referring to this troubling crime, examples being stock theft (South Africa), cattle raiding (European countries and the United States of America USA), cattle rustling (Eastern and Northern Africa), lifting (India) and cattle duffing (Australia). Irrespective of the international classification of crime for statistical purposes as proposed by the United Nations on Drugs and Crime (UNODC), the South African CJS does not provide for the different categories of this crime (Clack 2018).

The noteworthy impact of agriculture on both the international economies and rural areas is widely noticed and appreciated. Agriculture is often associated with an idyllic rural environment in which crimes and other social problems are infrequent. Conversely, agriculture is susceptible to criminality, which can be overwhelming to both communities and the agricultural industry as a whole. Agricultural crime includes an array of property and environmental crimes committed within an agricultural setting (Clack, 2018).

Agriculture is regarded as the sole economic enterprise which delivers to the general creation of wealth in South Africa, calling for both small-scale and large-scale farmers to practice entrepreneurial agricultural activities. Entrepreneurship has been noted as a feasible drive and source for many countries' economic growth in contemporary society. This is regarded as a new phenomenon in agriculture especially in developing economies. For the [Livestock farmers] to maximise agricultural outputs, they gather their expertise to be able to endure unforgiving circumstances occurring due to environmental changes. Therefore; these outputs are incorporated using strategic entrepreneurship skills. Thus, an increase in agricultural productivity can successfully promote human development accommodating different levels of skills that can reflect their strengths and noticeably weaknesses (Mujuru, 2014).

In collaboration, a study by Choudhury and Easwaran (2019) explores the role played by farmer entrepreneurs in making farming a profitable livelihood avenue. The study in question shares that agricultural entrepreneurship is often construed as a means for empowering the rural [Livestock] farmers, as they are up against a myriad of glitches including human-wildlife conflict, irrigation, and improved variety of seeds. A common platform and unity amongst them regarding the prices of their products are very pivotal, as these farmers fail to get the benefits. Therefore, societal recognition is more important in pursuing an occupation like agricultural entrepreneurship.

Consequently, a general consensus stemming from development economics literature studies and other research on African economies and livelihoods suggests that smallholder livestock farming practices provide pathways out of poverty, further contributing towards food security and sustainable livelihoods. This is also supported by the Integrated Sustainable Rural Development Strategy of 2004 by stating that this practice as an agricultural activity can respond to food security and fight poverty in the small-scale communal farming areas in South Africa. Similarly, Vision 2030 of the National Development Plan sees agriculture as a vehicle for job creation in rural areas (Gumede, Maziya \& Chiumbu, 2018). As indicated by (ljatuyi, 2020), South Africa's National Small Business Act (No. 106 of 1996) defines a micro-enterprise as a "business having less than five employees, a very small business that has six to twenty workers, a small business to be employing twenty-one (21) to fifty (50) workers, and medium organisations to be the one that has less than two hundred (200) workers." The aim is to strengthen Small, Medium and Micro Enterprises (SMMEs) rests on creating employment and stimulate South Africa's economy, this prompted the formation of the Small Business Development Department (SBDD). Through this method, South Africa recognised the importance of small business growth to its economy with the hope that it can lead the path to a flourishing agricultural sector. The notable examples of SMEs in agriculture include the following factors:

- Input and technology producers: major in design, assembly, or manufacture equipment.

- $\quad$ Producers: sow, farm, and harvest crops, raise poultry and livestock farming or fish

- Logistics, trade, and distribution provide logistics, distribution, and trade services for agricultural produce. 
- Processors: they process and package agricultural products for sale to customers or traders.

- Wholesalers: procure raw or processed products from farmers and processors to export or sell to retailers or processors.

- Retailers: they sell agricultural products to consumers through retail markets (Cant \& Wiid, 2013).

Conversely, the study conducted by Lombard and Bahta (2019) estimates that the financial impact (I.e. Direct and indirect costs) of stock theft. This was done to identify different methods the livestock farmers used to control stock theft in South Africa. The data collected from 292 commercial livestock farmers from the five municipalities of FS Province. This study revealed that the direct and indirect cost of stock theft rate was significant and mostly a higher level of management, leading to lower stock theft losses. Certainly, this crime should be controlled successfully to sustain the South African livestock industry and competitiveness [I.e. Entrepreneurial activities in South African rural areas are no exception].

Subsequently, the cited study recommends that there should be coordination and collaboration among all key role players in the industry including government institutions, the local SAPS, Agricultural Businesses or other relevant stakeholders organisations, Farmer's Unions, and SAPS STUs. The role players should target, eradicate or reduce stock theft and encourage controlling mechanisms to enhance food security, sustain livestock competitiveness and achieve sustainable development goals by reducing hunger and poverty. In particular, the year 2020 revealed that the Water Users Association (WUA) is struggling with more common problems, such as pumping, filtering or thefts [Stock theft included], and are not focused on the transition to new technologies. Moreover, they are not willing to make this kind of investment in a complex agroindustry system with very low economic benefits and securities (González-Pavón, Arviza-Valverde, Balbastre-Peralta, Sierra \& Palau-Salvador, 2020). Significantly, agriculture and livestock farming practices form part of the traditional survival strategy of much rural farming across South African communities (Mugwabana, Muchenje, Nengovhela, Nephawe \& Nedambale, 2018).

Evidentially, a deluge of evidence is available which highlights agriculture as a contributor to economies globally, especially to rural communities (Clack, 2020). Yet, although agriculture is crucial to the economy of many countries, and an idyllic perception of a crimefree environment is portrayed, in reality, these areas are vulnerable targets of crime. Agricultural crime can be negatively overwhelming to rural communities and the agricultural field as a whole (Clack, 2020). The most essential facet is that rural areas differ and individual farms have unique requirements for entrepreneurial enterprise or prevention of this crime.

The Sustainable Agricultural Practices (SAPs) are the most promising pathways to enhance the productivity, [business enterprise], and resilience of agricultural production of smallholder farming systems while conserving the natural resources. The majority of the farmers in the study area have greatly restricted access to credit due to their low income, old age, and low level of education, whereas those who satisfy the elementary credit requirements are more likely to invest their money in other enterprises, such as tuckshops, rather than agriculture.. This is owing to the agricultural uncertainties of production due to poor crop produces associated with land degradation, climate change, and stock theft (Myeni, Moeletsi, Thavhana, Randela \& Mokoena, 2019).

For the objective of this study, the following section discusses each aspect of the Timmons Entrepreneurial Processes Model in terms of stock theft causations and prevention measures:

\section{TIMMONS' MODEL OF THE ENTREPRENEURIAL PROCESS: AN APPLICATION}

The Timmons Model Entrepreneurial Process focuses on the entrepreneur. Thus, entrepreneurship according to Timmon's model denotes the establishment of new organisations (Zhang \& Yang 2006). Entrepreneurship centers on the establishment of the new venture and business development with the already recognised or well-established companies than to just commence the business. This also offers pursuits for greater opportunities, for a greater potential venture by assembling a team and gather essential resources to instigate a business intended to capitalises on availability opportunities (Brem 2011). Zeng, Bu, and Su (2011) state that the process commences with the opportunity, rather than money, strategy, networks, the team, and business plan, among others.

As presented in Figure 1 of this study; this 'Model' prefers opportunities, teams, and resources as the 
three essential available factors to an entrepreneur and embrace that accomplishment rest on the capability of the entrepreneur to balance the fundamental factors. According to Timmon's framework, there are three elements of a prosperous new business: the opportunity, the entrepreneur and management team are highly sought and if it is a greater potential venture, and the resources required to instigate the company and make it enormous (Bygrave \& Zacharakis, 2011). This model prefers opportunities, team, and resources as the three essential factors and concludes that the achievement of an entrepreneur rests upon the capability to balance all these three factors (Ghee \& Poerwowidagdo, 2010). Therefore, it commences when an entrepreneur detects an opportunity that chooses the size and type of team and other needed resources such as funds, technologies, and labour to make the most out of the identified opportunity (Whitehead, 2011).

\section{The Opportunity Factors}

Opportunity is defined by Austin, Stevenson, and Wei-Skillern (2012) as the belief of achievement, which is possible and required for a future state that is distinct from the present. Moreover, opportunity in the social and commercial sectors needs an investment of uncommon resources with the belief of future benefits. However, the realisation of opportunities consists of identifying a market or a crew of individuals focusing on a given challenge. Thus, solving this challenge frequently encompasses the establishment of creative and new tactics (Tshikovhi \& Shambare, 2015) and (Venkataraman \& Shane, 2000). Brem (2011) postulates that opportunities are intended for the utilisation of opportunities by every individual. Identification of the right opportunity ensures business success (Ghee \& Poerwowidagdo, 2010). Doerr (1997) individuals are driven by the opportunity process as a fundamental factor while secluding other essential components required to instigate a business. Furthermore, Brockner, Higgins, and Low (2003) suggest that a threatening environment may suppress entrepreneurial activity. Thus, high incidences of stock theft may suppress their desire or dreams as entrepreneurs to create new ventures. This element collides with the routine activities associated with the commission of this crime as discussed by Maluleke, Mokwena, and Olofinbiyi (2019), they revealed that the determining factor of this crime relates to the activities of potential stock thieves and livestock farmers. Therefore, the three important elements that influence this crime and negatively impact the inception of entrepreneurship enterprises as follows:

- The availability of a suitable target, referred to different types of and available protections to them. Clack (2014a) provides that all stolen livestock (I.e. Cattle, sheep, and goats) have a specific factor, making them more or less suitable targets. The availability of livestock in a location should be taken into consideration. For example, "cattle are large and is difficult to transport, sheep are regarded as dumb (not intelligent) animals that flock together when herded and normally do not make a noise at night when disturbed, while goats will blaze like crazy."

- The absence of capable guardians, is demarcated to the available legislations and security personnel of policing this crime. Clack (2014a) notes that this component is ascribed to the lawful holder or owner of the livestock, other relevant stakeholders, and the CJS as a whole. Adherence to the legislative frameworks, such as the Stock Theft Act (No. 57 of 1959) and the Animal Identification Act (No. 6 of 2002) and other relevant legislations are essential in this regard.

- The presence of motivated offenders, can be confined to unhappy or financially challenged stock theft thieves or herd boys. Clack (2014b) highlights that lack of research on profiling livestock thieves to suggest motivations of alleged offenders contribute negatively to this element. However, the completed Master's degree study in 'Criminology' as conducted by a University of South Africa (UNISA), Miss Cecili Doorewaard as examined by one of the authors in the 2020 academic year, is believed that it is going to look into this element acutely. For speculations motives; the value of livestock, different from that of other merchandises, is not lost when stolen; livestock does not only have a monetary value, it may provide food for the offender's family; and the offender may be involved in this crime based on greed or a need to feed the family (Clack, 2014b).

Lombard (2020) further reveals that the discussed three elements discussed are essential for stock theft to be committed, namely: A willing criminal, a suitable target (Property), and the absence of a competent guardian (Owner). 


\section{The Resources Factor}

Untried entrepreneurs are of the notion that an individual should initially be equipped with all the necessary means in place such as money to succeed with a venture (Parizeau, 2001). The second pushing force in the process is the availability of resources. Thus, Funds, land, labour, and technologies, are among the required resources (Goodale, Kuratko, Hornsby \& Covin, 2011). Resources for an entrepreneur's project comprise of components required to establish finances, assets, and equipment (Rwigema \& Venter, 2004).

In connection to the effects of stock theft on entrepreneurial segment of the available resources factor; Maluleke (2018) states that this organised property-related crime, cause significant ripple effects on the South African economy. It was reported in 2018, this crime costs the livestock industry approximately R500 million. Some factors contribute to stock theft, and they are: Unattended grazing, the practice of keeping unmarked livestock, and poor documentation of the movements of livestock. These issues are also propelled by recurring acts of vigilantism, often associated with bitter and violent conflict at the communal levels. Therefore, adequate resources are required to respond to this scourge, Maluleke (2014) supports this submission by revealing that it is of critical significance for the local SAPS STUs personnel to be regularly provided with appropriately advanced training to develop policing knowledge of Stock theft, to further improve their investigations and analytical skills. The SAPS STUs of the selected provinces should be encouraged to share, and co-ordinate their intelligencegathering, analysis of their capabilities they should establish a unified stock theft syndicate threats strategic view. In instances where there is a shortage of personnel at the local SAPS STUs, officers attached to the local police stations, and its detective's services, who have completed specific courses related to the investigations of this crime, should continue to support the local SAPS STUs in their investigations, this arrangement can afford these investigators an opportunity to become familiar with all aspects relating to the investigation of this crime.

This 'Model' discounts the popular idea than extensive resources to decrease the risk of instigating a venture and encourages bootstrapping or beginning with the only minimal requirement as a manner to gain competitive privileges. The role of the entrepreneur in managing the resources encompasses establishing a great resource base to draw from when needed and drawing up a business plan with a fit and balanced method that can balance the available resource with the opportunities and the capabilities of the team (Ghee \& Poerwowidagdo, 2010).

Furthermore, Maluleke (2016) highlights that the resource factor of this model can be best understood if the local SAPS STUs tasked to combat stock theft can be provided with adequate capacity and resources to respond effectively against this crime. It is believed that the responsible units are operational, but with limited capacity and resources. The lack of training also makes it difficult to meticulously collect necessary Deoxyribonucleic Acid (DNA) evidence and samples to provide the foundation for successful prosecutions, which is one of the limited resources cited by this study. The literature consulted by this study proved that by September 2020; there were approximately 90 SAPS STUs across South Africa, with less than two thousand members and less than one thousand vehicles. The members of these units of the selected provinces can respond to any crime scene anywhere in the country, also working closely with SanParks, which specifically concentrate on poaching of endangered species such as 'Elephants and Rhino.' Similarly, it is noted that the local rural livestock farmers heavily on branding and tattooing to protect their livestock against related theft, which meant the implementation of DNA technology was underutilised. The SAPS management should consider building their forensic science laboratory, to focus on stock theft in those provinces most severely affected by this scourge. It is highly recommended that local SAPS management reconsider the sole use of the Animal Genetics Division (AGD) of ARC -Irene, as its efficiency and capacity are currently being questioned (Maluleke \& Mofokeng, 2018).

Based on this 'Model,' the researchers hypothesise that livestock farmers' entrepreneurs will experience increasing difficulties in the process of gathering the necessary resources to commence their businesses, as they might lack adequate resources to initiate these businesses and they might not see their livestock keeping as a business model. Different livestock gets stolen timely across South Africa, with limited solutions geared towards effectively responding to this scourge.

\section{The Team Factor}

The entrepreneur works to establish a business by placing together the team and collecting the required 
resources once the opportunity is identified. The size and shape of a team are determined by the size and the nature of the present opportunities. (Zeng, Bu \& Su, 2011).

In connection to the entrepreneurial value and the team factor, a study conducted by Manganyi, Maluleke, and Shandu (2018) made a deduction that co-operative strategies in the policing of stock theft seem to be inadequate to reduce this rural crime for the betterment of the efficient business enterprise.

Notably, every new business ventures need a greater entrepreneurial team. As per 'Timmon's Model Process; establishing an effective team is a pivotal aspect of the entrepreneurial process. The entrepreneur requires a proper strategy to bring together a competent and experienced management team that can focus on day-to-day business operations and dexterous enough to fight any uninvited circumstances or event. This team will, therefore, drive the company towards the appropriate direction, which will result in expansion and success (Wahl \& Prause, 2013).

The success of any entrepreneurial venture rests to a substantial extent on the cohesion of the entrepreneurial team (Barringer, Jones \& Neubaum, 2004). The local livestock farmers attempting to work as a team or establish networks within the sector seem to be insufficient regarding entrepreneurial edge to maintain this sector, they may be forbidden and secluded by the local Department of Agriculture, Forestry, and Fisheries (DAFF) or any other relevant stakeholder, or they may find it extremely challenging to communicate and do business with other local livestock farmers. As a result, team members might not see the importance of livestock farming practices owing to stock theft.

\section{CONCLUSION AND RECOMMENDATIONS}

In summation, this study holds that most of the rural livestock farmers in the selected provinces are losing out based on stock theft are the underprivileged South Africans. However, as a result, they lose hope, which leads to a general suppressing and decline of entrepreneurial activity amongst this group. The fact that livestock farming practices do not operate, as well as they, would under better circumstances, means that additional work opportunities for South Africans are lost due to diminished entrepreneurial activity. It is not only these farmers who feel neglected also foreign investors may think twice before investing in a country, which manifests such a high level of crime [l.e. Stock theft]. At this time most of the stock theft is directed at different livestock, such as Cattle, Goats and Sheep. However, if it is not effectively controlled, the effects of this crime can be drastically, further spilling over into the formal business sector. The issue of stock theft and entrepreneur is a serious one; further extensive research is needed to understand and prevent future occurrences of this crime to enhance the anticipated business model in this sector.

To this course, Lombard (2015) recommends that support should be provided to the livestock farmers either by government institutions, the SAPS STUs, and other agricultural businesses or organisations. If stock theft is not successfully controlled in the selected provinces, it will not only threaten the sustainability of the South African livestock industry but also the competitiveness of the envisaged business enterprises of this sector. Management advice that can be formulated based on the study, is that livestock farmers especially (Sheep farmers) should count their livestock daily. If the farmer is unable to count the livestock daily.

Moreover, the National government (Provincial and local - Cluster and municipal spheres of governments), agricultural industries as a collective, and commodity organisations have to share responsibilities to enable required services to effect a viable enabling effective environment. A visible and robust commitment must be depicted by the indicated government spheres and livestock industries. Additionally, this sector may need a paradigm shift by responsible agricultural industries, focusing on two key elements of community policing, namely; partnerships and problem-solving techniques, which are not commonly employed. Moreover; border and fence control, laboratory and testing services, improvement schemes, Research and Development ( $R$ $\& D)$, technology transfer and training, must be entirely unified. Likewise, commodity organisations must take greater responsibility in succoring a minimal-scale and new farmers to becoming entirely-fledged commercial farmers. Job establishment, poverty alleviation, food security, rural stability, and a healthy and sustainable industry can be achieved through livestock agriculture in South Africa (Meissner, Scholtz \& Engelbrecht, 2013).

\section{REFERENCES}

Agriculture South Africa. 2018. Crime Statistics on farms confirm worrying extent. Available at: https://www.farmersweekly. 
co.za/agri-news/70-commercial-farmers-experienced-crime2017/attachment/agrisa_crimestatistics_v2/.

Animal Research Council [Online]. 2014.Animal Genetics-DNA Forensics is the key to resolving stock theft in South Africa. Available at: https://www.arc.agric.za/arc-api/Pages/AnimalGenetics.aspx.

Austin, J., Stevenson, H and Wei-skillern, J. 2012. Social and commercial entrepreneurship: same, different, or both? Revista de Administração, 47(1): 370-384. https://doi.org/10.5700/rausp1055

Barringer, BR., Jones, FF and Neubaum, DO. 2004. A qualitative content analysis of the characteristics of rapid-growth firms and their founders. Journal of Business Venturing, 20(1): 663-689. https://doi.org/10.1016/j.jbusvent.2004.03.004

Ben, B., Moreki, JC., Wame, B., Kebadire, T and Lesaba, K. 2018. A survey of livestock theft at Mogonono village in Kweneng District of Botswana. Journal of Animal Science and Veterinary Medicine, 3(4), 94-10. https://doi.org/10.31248/JASVM2018.100

Brem, A. 2011. Linking innovation and entrepreneurship: Literature overview and introduction of a process-oriented framework. International Journal of Entrepreneurship and Innovation Management, 14(2): 6-35. https://doi.org/10.1504/IJEIM.2011.040820

Brockner, J., Higgins, ET and Low, MB. (2004) Regulatory focus theory and the entrepreneurial process.Journal of Business Venturing, 19(2): 203-220. https://doi.org/10.1016/S0883-9026(03)00007-7

Bunei, EK. 2017. Keynote Address: Stock theft in Africa: Current challenges and future direction. Available at: https://www.rpo. co.za/wp-content/uploads/2016/04/Bunei_Stock-theft-inAfrica_20170925.pdf.

Bygrave, WD and Jeffry, A. 1992. Timmons, venture capital at the crossroads. Harvard Business School Press: Boston.

Bygrave, WD and Zacharakis, A. 2011. Entrepreneurship. John Willy \& Sons: Babson Park.

Cant, M. C and Wiid, J. A. (2013). Establishing the challenges affecting South African SMEs. The International Business and Economics Research Journal, 12(6), 707-714. https://doi.org/10.19030/iber.v12i6.7869

Chelin, R. 2019. Organised crime moves in on South Africa's livestock industry. 19 November, Daily Maverick and ICSS Today [Online]. Available at: https://issafrica.org/isstoday/organised-crime-moves-in-on-south-africas-livestockindustry.

Choudhury, K and Easwaran, K. 2019. Agricultural entrepreneurship in lower Brahmaputra Valley, Assam. Journal of Global Entrepreneurship Research, 9(59), 1-13. https://doi.org/10.1186/s40497-019-0179-x

Clack, WJ. 2019. A comparison of rural crimes in Australia (NSW) and South Africa (2019). International Journal of Rural Law and Policy, Special issues on Rural Crime, 2(1), 1-20. https://doi.org/10.5130/ijilp.2.2019.6467

Clack, WJ. 2018. Livestock theft a global and South African perspective. Livestock theft report. National Red Meat Producers Congress 11 and 12 September 2018, Royal Elephant Hotel and Conference Centre, Pretoria.

Clack, WJ. 2014a. Livestock theft comparison. Wolboer / Wool Farmer, South Africa, (2(1), 40, 2307-0226.

Clack, WJ. 2014b. Livestock theft in theoretical context. Wolboer / Wool Farmer, South Africa, 2 (2): 57-59, 2307-0226.

Clack, WJ. (WClack@unisa.ac.za). 2021. Information as requested. [Email to:] Maluleke W. (witness.maluleke@ul.ac.za) January 24.

Clack, WJ. 2013. The extent of stock theft in South Africa. Acta Criminologica: Southern African Journal of Criminology, 26(2), 77-91.
Clack, WJ. 2018. Rural crimes: non-reporting of livestock theft by farmers. Acta Criminologica: African Journal of Criminology and Victimology, 31(4), i-vii.

Clack, WJ. 2020. Livestock prevention In: Rural crime prevention: Theory, tactics and techniques. Edited by Harkness, A Routledge: Britain. https://doi.org/10.4324/9780429460135-23

Commey, P. 2007. South Africa's: A bad way to treat fellow Africans. Available at: https://www.gale.com/databases/questia.

Corrigan, T. 2019. Stealing the future of farming. May 17, South African Institute of Race Relations [Online]. Available at: https://irr.org.za/media/stealing-the-future-of-farmingfarmersweekly.

Dedekind, LJ. 2016. Investigating Livestock Dynamics in Relation to Livestock Water Productivity in Smallholder Mixed CropLivestock Systems: A Case Study of Ntshiqo in the Eastern Cape. Unpublished Master of Science, in the School of Agricultural, Earth and Environmental Sciences. University of KwaZulu-Natal: Pietermaritzburg.

Doerr, J. 1997. John Doerr's Start-Up Manual. Fast Company, 1 (4): 82-84.

FTW Online. 2019. Stock theft rise expected to cost economy R200m more. Available at: www.ftwonline.co.za.

Geldenhuys, K. 2020. Stock theft: A costly, cruel crime. Available at: https://servamus.co.za/index.php/servamus/july-2016/493stock-theft-a-costly-cruel-crime.

Gaertner, S. 2000. Reducing intergroup bias: The common in-group identity model. Psychology Press: New York.

Gerhard, D., Brem, A., Baccarella, C and Voigt, KI. 2011. Innovation management and marketing in the high-tech sector: $A$ content analysis of advertisements. International Journal of Management, 28(1): 1 Part 2. https://doi.org/10.2139/ssrn.2433961

Ghee, WY and Poerwowidagdo, SJ. 2010. Entrepreneurial logistics: An application of Timmons Model in the mini business project for undergraduate business students. Advances in Social Sciences Research Journal, 5(10), 511-520. https://doi.org/10.14738/assri.510.5541

González-Pavón, C, Arviza-Valverde, J, Balbastre-Peralta, I, Sierra, JMC and Palau-Salvador, G. 2020. Are water user associations Prepared for a second-generation modernisation? The case of the Valencian Community (Spain). Water Journal, 12, 1-17. https://doi.org/10.3390/w12082136

Gough, D, Oliver, S and Thomas, J. 2012. An introduction to systematic reviews. London: Sage.

Goodale, JC., Kuratko, D.F., Hornsby, JS and Covin, JG. 2011 Operations management and corporate entrepreneurship: The moderating effect of operations control on the antecedents of corporate entrepreneurial activity in relation to innovation performance. Journal of Operations Management, 29(1):116-127.

https://doi.org/10.1016/j.jom.2010.07.005

Grobler, J. 2019. Farming community's safety is a priority. August 19, Agri SA [Online]. Available at: https://www.politicsweb.co.za/news-andanalysis/farmingcommunitys-safety-is-a-priority--agri-sa.

Gumede, NA., Maziya, M and Chiumbu, S. 2018. Gender dynamics within small-scale farming: narratives of smallholder livestock farmers in five provinces, South Africa. Human Sciences Research Council: Pretoria.

Flick, U. 2015. Introducing research methodology. Thousand Oaks, CA: Sage.

Eye Witness News [Online]. 2020. Stock theft must be escalated, treated as serious economic crime - Cele. Available at https://ewn.co.za/2020/11/12/stock-theft-must-be-escalatedtreated-as-serious-economic-crime-cele. 
ljatuyi, EJ. 2020. Effects of award incentives and competition on entrepreneurship development among female farmers in North West Province. Unpublished Doctor of Philosophy in Agriculture with Agriculture Extension. North-West University: Potchefstroom.

Kaulitz, W. 2012. The Timmons Model of the Entrepreneurial Process.

https://doi.org/10.1007/978-3-642-31098-0 3

Lombard, WA. 2015. The financial impact of sheep theft in the Free State Province of South Africa. Unpublished Magister Scientiae Agriculturae. University of the Free State: Bloemfontein.

Lombard, WA. 2020. Livestock theft: The short end of the stick. May 22, Agri Orbit. Available at: https://www.magzter.com/stories/Business/Stockfarm/Livesto ck-theft-The-short-end-of-the-stick.

Lombard, WA. 2017. What is the actual cost of stolen livestock. Red Meat / Rooivleis, 8 (2): 54-57.

Mahlobo, BT. 2016. Multi-criteria livestock assessment for sustainability of smallholder farms in Kwa-Zulu Natal. Unpublished Masters in Sustainable Agriculture (Animal Sciences), Faculty of AgriSciences. Stellenbosch University: Stellenbosch.

Mujuru, JTR. 2014. Entrepreneurial agriculture for human development: A Case study of Dotito irrigation scheme, Mt Darwin. International Journal of Humanities and Social Science, 4 (4), 121-131.

Nicolson, G and Simelane, B. 2020. Farmers, stock thieves and the police: Battle lines are drawn in Free State. October 15, Daily Maverick. Available at: https://www.dailymaverick.co.za/ article/2020-10-15-farmers-stock-thieves-and-the-policebattle-lines-are-drawn-in-free-state/.

Lombard, WA and Bahta, YT. 2019. Stock theft control mechanism and economic impact of livestock theft in the Free State Province of South Africa: Implication for agricultural management policies. International Journal of Agricultural Management, 8(3), 1, 98-106(9).

Maluleke, W. 2014. Perspectives on stock theft prevention in the giyani policing area of Limpopo Province. Unpublished Magister Technologiae: Policing. Tshwane University of Technology: Soshanguve South.

Maluleke, W. 2018. The integration of conventional and technological methods in combating stock theft by selected stakeholders in the KwaZulu-Natal Province. Acta Criminologica: Southern African Journal of Criminology, Special Edition, 31(4), 123146

Maluleke, W. 2016. The use of Deoxyribonucleic Acid in combating stock theft in South Africa. Unpublished Doctor Technologiae: Policing. Tshwane University of Technology: Soshanguve South.

Maluleke, W., Mokwena, RJ and Olofinbiyi, SA. 2019. An evaluative study on criminalistics: stock theft scenes. International Journal of Business and Management Studies, Vol 11, No. 1, 101-138.

Manganyi, FM., Maluleke, W and Shandu, SN. 2018. An examination of co-operative strategies towards policing stocktheft in the KwaZulu-Natal Province. Acta Criminologica: Southern African Journal of Criminology, Special Edition: Rural Crime, 31(4), 97-122.

Maluleke, W and Mofokeng, JT. 2018. Challenges facing the implementation of Deoxyribonucleic Acid technology in combating stock theft in KwaZulu-Natal province, South Africa. International Journal of Social Sciences and Humanity Studies, 10(1), 311-345.

Maluleke, W., Mokwena, RJ and Motsepa, LL. 2016. Rural farmers' perspectives on stock theft: police crime statistics. South African Journal of Agricultural Extension, 44 (2), 256-274. https://doi.org/10.17159/2413-3221/2016/v44n2a393
Matthews, B and Ross, L. 2010. Research methods. A practical guide for the social sciences. Pearson Education:Harlow, Essex.

Meissner, HH., Scholtz, MM and Engelbrecht, FA. 2013. Sustainability of the South African Livestock Sector towards 2050 Part 2: Challenges, changes and required implementations. South African Journal of Animal Science, 43 (1), 298-319. https://doi.org/10.4314/sajas.v43i3.6

Morton, N. 2020.Rural crime: Stock theft has cost farmers millions already this year. 28 July, Western Magazine [Online]. Available at: www.westernmagazine.com.

Mugwabana, TS., Muchenje, V., Nengovhela, NB., Nephawe, KA and Nedambale, TL. 2018. Challenges with the implementation and adoption of assisted reproductive technologies under communal farming system. Journal of Veterinary Medicine and Animal Health, 10(10), 237-24.

Myeni, L, Moeletsi, M, Thavhana, M, Randela, M and Mokoena, L. 2019. Barriers affecting sustainable agricultural productivity of smallholder farmers in the Eastern Free State of South Africa. Sustainability Jornal, 11(11), 1-18. https://doi.org/10.3390/su11113003

National Stock Theft Prevention Forum. 2019. Press release Livestock theft crime statistics. National Stock Theft Prevention Forum: Persequor Park.

Nicolson, G. 2020. Crime Stats: Murder rate remains 'stable' at around 58 deaths a day. 31 July, Daily Maverick [Online]. Available at: https://www.dailymaverick.co.za/article/2020-0731-crime-stats-murder-rate-remains-stable-at-around-58deaths-a-day/.

Parliamentary Monitoring Group [Online]. 2015. Questions to Police. Available at: https://pmg.org.za/committee-question/11636/.

Parizeau, MH. 2001. Are the universities and sciences subservient to the economy? A summary and analysis. ISUMA: Canadian Journal of Policy Research,2(1): 133-141.

Pijoos, I. 2020. I've seen the stock theft figures, it's hell - Bheki Cele tells farmers. November 12, Sowetan Live. Available at:https://www.sowetanlive.co.za/news/south-africa/2020-1112-ive-seen-the-stock-theft-figures-its-hell-bheki-cele-tellsfarmers/.

Rwigema, $\mathrm{H}$ and Venter, R. 2004. Advanced entrepreneurship. Cape Town: Oxford University Press.

Sarasvathy, S.D., Dew, N and Velamuri, S.R. 2002. A testable typology of entrepreneurial opportunity: Extensions of Shane and Venkataraman (2000). Academy of Management Review: United States.

Sehar, M. 2018. Factors influencing market access and livestock marketing inefficiency in Mpumalanga Province, South Africa. Unpublished Master of Science. University of South Africa: Pretoria.

Shane, S and Venkataraman, S. 2000. The promise of entrepreneurship as a field of research. Academy of Management Review, 25 (1): 217-226. https://doi.org/10.5465/amr.2000.2791611

Stanford University's Entrepreneurship Corner [Online]. 2006. Jefferey A. Timmons. Available at: https://ecorner.stanford.edu/.

TimesLive [Online]. 2020. Stock theft 'serious', with 26,000 sheep stolen in 3 months. November 13, Go! and Express. Available at: https://www.timeslive.co.za/news/southafrica/2020-11-13-crimestats-stock-theft-serious-with-26000sheep-stolen-in-3-months/.

Timmons, J.A. 1999. New venture creation: Entrepreneurship for the $21^{\text {st }}$ century. McGraw-Hill: Singapore.

Tshikovhi, N and Shambare, R. 2015. Entrepreneurial knowledge, personal attitudes, and entrepreneurship intentions among South African Enactus students. Problems and Perspectives in Management, 13(1): 152-158. 
The Economist. 2020. Where's the beef? Livestock theft is becoming more common in South Africa. Available at: https://www.economist.com/middle-east-andafrica/2020/11/19/livestock-theft-is-becoming-morecommonin-south-africa.

Van den Heever, M and Lombard, WA. 2018. An overview of rural crime and prevention devices.FarmBiz, 1 (2): 6-7.

Wahl, M and Prause, G. 2013. Toward understanding resources, competencies, and capabilities: business model generation approach. Entrepreneurship and Sustainability Issues, 1 (1): 67-80.

https://doi.org/10.9770/jesi.2013.1.2(1)
Whitehead, AN. 2011. Science and the modern world. Simon and Schuster: New York City.

Zeng, FQ., Bu, XZ and Su, L. 2011. Study on entrepreneurial process model for SIFE student team based on Timmons model. Journal of Chinese Entrepreneurship, 3 (1), 204-214. https://doi.org/10.1108/17561391111166984

Zhang, Y and Yang, J. 2006. New venture creation: evidence from an investigation into Chinese entrepreneurship. Journal of Small Business and Enterprise Development, 13 (2), 161-173. https://doi.org/10.1108/14626000610665872

Received on 06-01-2021

https://doi.org/10.6000/1929-4409.2021.10.110

(C) 2021 Mabunda et al.; Licensee Lifescience Global.

This is an open access article licensed under the terms of the Creative Commons Attribution Non-Commercial License (http://creativecommons.org/licenses/by-nc/3.0/) which permits unrestricted, non-commercial use, distribution and reproduction in any medium, provided the work is properly cited. 